\title{
Concluding remarks: overall impacts on biodiversity and future perspectives for conservation in the Pantanal biome
}

\author{
Alho, CJR.* \\ Programa de Pós-graduação em Meio Ambiente e Desenvolvimento Regional, \\ Universidade Anhanguera - Uniderp, CEP 79037-280, Campo Grande, MS, Brasil \\ *e-mail: alho@unb.br
}

Received October 14, 2010 - Accepted December 13, 2010 - Distributed April 30, 2011

\begin{abstract}
The Pantanal biome is characterised by seasonal flooding which determines specific ecosystem processes, with the occurrence of adapted plants and animals to the annual shrinking and expansion of habitats due to the seasonal hydrological regime. Biodiversity abundance varies during the dry and wet seasons. The Pantanal's biodiversity is a fundamental component of ecosystem services for human society, including nutrient cycling, fish production, ecotourism, carbon storage, flood control, among others, which are relevant to regional and global environmental consequences. The biome has been impacted by the conversion of natural vegetation into agricultural fields and pasture for cattle raising, with alteration and loss of natural habitats and biodiversity. Major negative impacts occur in uplands, with drastic deforestation of savanna vegetation, where main rivers feeding the Pantanal have their springs. This article discusses future needs and priorities for ecological research, in order to better understand the biome's natural system, to achieve conservation and sustainable use.
\end{abstract}

Keywords: biodiversity, conservation, environmental impacts, habitats, Pantanal.

\section{Observações conclusivas: impactos ambientais sobre a biodiversidade e perspectivas futuras para conservação no bioma Pantanal}

\begin{abstract}
Resumo
O bioma Pantanal é caracterizado pela inundação sazonal que determina processos ecossistêmicos específicos, com a ocorrência de plantas e animais adaptados à mudança anual de encolhimento e expansão de hábitats em virtude do regime hidrológico sazonal. A biodiversidade do Pantanal é um componente fundamental dos serviços ecossistêmicos prestados à sociedade humana, que inclui reciclagem de nutrientes, produção pesqueira, ecoturismo, resgate de carbono, controle de enchentes, entre outros, que são importantes consequências ambientais em nível regional e global. O bioma tem sido afetado pelo impacto da conversão de sua vegetação natural em campos agrícolas e pasto para a pecuária, com alteração e perda de hábitats e biodiversidade. O impacto maior tem ocorrido nas terras altas do planalto do entorno da planície, com desmatamento do Cerrado nas áreas onde nascem os rios que alimentam o Pantanal. Este artigo discute as necessidades e prioridades futuras de pesquisa ecológica para melhor entender o ecossistema e, assim, atingir sua conservação e uso sustentável.
\end{abstract}

Palavras-chave: biodiversidade, conservação, impactos ambientais, hábitats, Pantanal.

\section{Land Use}

The loss of natural habitats and their associated biodiversity in the Pantanal have been drastic during the last decades, particularly in the upland region of the Cerrado plateaus surrounding the flooding plain (Silva et al., 2010; Conservação Internacional, 2009). The study by Silva et al. (2010) analysed the deforestation of the Pantanal and its surroundings over the past 30 years. Deforestation in the Pantanal increased about 20 times in the period, reaching near $15-20 \%$ of its area. Deforestation in the Upper Paraguay River Basin reached more than $40 \%$. The
Pantanal still retains about $80 \%$ of its natural vegetation, but the upper reaches of the Paraguay River basin have lost about $60 \%$ of its natural vegetation cover, with a higher rate of deforestation in the highland areas of the basin.

Agriculture (mainly soybean) and cattle ranching is prevalent in highlands but in the northern region of the river basin, mining has been active since the beginning of the XVIII century (Casarin, 2007). Mining is responsible for environmental degradation in the region of the Paraguay/Diamantino watershed, resulting in erosion 
with revolved soil due to mining processing. In addition, deforestation for agriculture and cattle pasture cause erosion mainly in slope terrains and mountain hillsides of the highlands.

While at the international level, the Ramsar Convention on Wetlands was established to protect wetlands, on the national level, Brazil has signed the Convention and designated the Pantanal as a Ramsar site. On the other hand, Brazilian environmental legislation has been recognised as updated, but difficult to enforce due to a weak environmental institutional structure, mainly in the two states (Mato Grosso and Mato Grosso do Sul) which comprises the Pantanal.

\subsection{Environmental impacts affecting biodiversity}

The Pantanal has been negatively impacted by unsustainable socio-economic development through predatory land use (Alho, 2005). Major economic activities are cattle ranching, fishing, agriculture, mining and tourism. Deforestation to convert natural habitats with pastures for cattle is increasing. The consequence is loss of biodiversity, for example, removal of forest that eliminates food and shelter, for forest-dwelling wildlife. Environmental pollutants are introduced from uncontrolled use of pesticides and herbicides, contamination with mercury from unregulated gold mining, urban liquid and solid waste, including untreated sewage, introduction of invasive exotic species, unsustainable tourism, illegal hunting, traffic of wildlife, soil degradation, lack of education and environmental consciousness, and fragility of environmental organizations to enhance legislation.

\subsection{Needs to identify, evaluate and mitigate environmental impacts}

Future development projects that affect the biome's biodiversity should only be undertaken after proper and thorough environment assessment procedures, based on specific terms of reference and public participation. Establishment of scoping to identify which potential impacts are relevant to assess, based on legislation, international conventions, technical and scientific knowledge and public involvement, to correct analysis to license projects or to reject them.

Brazilian public attitudes toward nature in general, and biodiversity in particular, have improved, and there has been more drive to protect the Pantanal. It would constitute progress to protect the ecological relationship between the floodplain, which is the Pantanal, and its surrounding upland plateaus, to apply environmental flow assessment (EFA) in any development project that affects river flow. This should apply for the hydroelectric plants being established in rivers that feed the Pantanal. This procedure should determine how much of the natural flow regime of a given river should continue to flow down to the Pantanal floodplain in order to maintain ecosystem processes. If on the one hand, development projects are good for the region, on the other, conservation priorities have to be carried out in order to fulfill ecological needs.

\section{Research Priorities}

It has become evident, because of the importance of the Pantanal biome, that scientific research is needed to improve conservation on the basis of scientific methods, in order to discuss the progress, problems and priorities to achieve sustainable use in the region. Scientific research improves our understanding of the magnitude of biodiversity, land use, and contributes to mitigating land use impacts. Incorporating research results into an action plan for biodiversity conservation of the Pantanal is an important part of the adaptive management process. The following are identified research priority topics for science-based conservation, protection and management:

- Studies on ecological processes to better understand the function of natural ecosystems;

- Hydrology studies to establish the relationship and dependence of river flow from highlands to floodplain in connection to the kinds of habitats and their associated biodiversity;

- Studies on fish movement, dispersal of semi-aquatic and aquatic mammals and other organisms, in relation to flooding regime to determine their significance and sensitivity to hydrological seasonal events and offer of ecological resources;

- Emphasis on the magnitude of the biodiversity, including ecological parameters such as species richness and species diversity of all types of wild plants and animals;

- Studies on habitats and microhabitats requirements and selection for wildlife in relation to seasonal offer of resources;

- Conservation action including protected areas, ecological corridors; feeding and reproductive niches of wildlife;

- Effects of habitat heterogeneity and other landscape factors on demography and recruitment of indicator species of insects, herpetofauna, fish, birds and mammals;

- Need to understand the effect of ecological processes on biodiversity responses (ecological parameters and behavioural patterns) to factors measured in different kinds of habitats and at landscape scales;

- Dispersal movements of wildlife, including fish, amphibians, reptiles, birds and mammals between feeding niches and reproductive niches as a function of seasonal annual variation;

- Migration routes especially of bird species;

- Studies on feeding and reproductive guilds of birds and bats;

- Habitat selection and microhabitats of small mammals (rodents and marsupials);

- Studies on environmental components selected by small mammals in relation to habitat selection and microhabitat types; 
- Identification and analyses of bioindicators for habitat quality and for degrees of disturbances;

- Studies on ecological communities structure and function in relation to ecological processes of the Pantanal;

- Considerations on consumptive and nonconsumptive activities in the Pantanal as a means of improving ecotourism to achieve sustainable use of the biodiversity.

- Identification and evaluation of impacts and development of alternatives, to predict and identify environmental impacts of proposed projects;

- Monitoring, enforcement and environmental auditing mitigation projects to verify the compliance of proponents to ensure mitigation and compensation impacts according to Federal and State legislation;

- Impact of invasive exotic species on population, community and ecosystem structure and function;

- Identification and analysis of categories of activities known to cause biodiversity impacts including ecotourism;

- Studies on priority areas for conservation, including production of maps indicating conservation categories according to Brazilian legislation; areas where impact assessment at an appropriate level is required; areas containing threatened ecosystems outside of formally protected areas; areas identified as being important for the maintenance of key ecological processes; areas known to be habitat for threatened species; areas identified as important cultural and spiritual components.

- Establishment of the cause and effect relationship between land use activities and biodiversity, with focus on: indicator species, human-caused impacts and aquatic integrity (macro-invertebrates as indicators); fish habitats and fishery; aquatic and semi-aquatic mammal species and dispersal in function of flooding regime; water quality indicators, and other contaminant indicators in relation to aquatic health;

- Establishment of benchmark conditions for regional sustainable development indicators for ecotourism and recreational areas;

- Research on climate change related risks in relationship to biodiversity and ecosystem integrity.

\subsection{Ecosystem services in connection with human well-being and research opportunities}

Ecosystem processes of the Pantanal maintain biodiversity by providing habitats for many plant and animal species. These processes produce products such as fish and other extractive resources. As a wetland, the biome is a productive ecosystem, providing seasonal nutrients for biodiversity. In addition to unsustainable land use and increasing economic development resulting in degradation of natural habitats, the Pantanal is also facing other threats including the consequences of climate change.

Independent of human benefit or intervention, an ecosystem works as an interdependent system in nature and biodiversity is an important component of this holistic system. However, during recent years, several published reports emphasise the role of ecosystem services for human being as a tool to apply conservation and protection (Costanza et al., 1997; Daily, 1997; Daily et al., 1997; Balmford et al., 2002; De Groot et al., 2002; Millenium Ecosystem Assessment, 2005a-k; Alho, 2008; Chivian and Bernstein, 2008; Mindell, 2009; Keddy et al., 2009; Cardinale et al., 2009). The concept of ecosystem services implies function and ecosystem processes, meaning the conditions through which natural ecosystems and biodiversity, that integrates the system, sustain and fulfill human life.

Ecosystem services are the benefits provided to humans as a function of ecosystem processes, like water quality, pure air, geobiochemical cycling of nutrients for plants and animals including importance for agriculture, wood, food, medicine and so on. It is the capacity of ecosystem processes to provide services and goods that satisfy human needs. These ecosystem processes are interactions among elements of the ecosystem or ecological attributes (physical, like solar energy and soil; chemical, like photosynthesis and cycling of nutrients; biotic, like primary production and secondary production, food chain and behavioral interactions) that are valued by humans.

The following ecosystem services of the Pantanal illustrate the importance of protected nature and show the relevance for scientific research:

- River flow. Natural river flows of hydrological cycles are fundamental for drainage, river discharge and seasonal inundation that influence habitats and biodiversity. They provide water quality for human consumption and nutrients for fishery.

- Nutrient cycling. Carbon, oxygen, hydrogen, nitrogen, phosphorus are cycled in ecosystems. Decomposition by soil organisms releases these and other elements into the soil and atmosphere so they can be used again. Nutrient cycling provides productive soil. Ecological processes play a role in storing and recycling organic matter, nutrients and human waste.

- Fishery. Fish is an important economic element of the Pantanal. Feeding and reproductive habitats of commercial fish depend on natural ecosystems.

\section{- Aesthetic, recreation and cultural attributes.} There is an increasing touristic industry in the Pantanal. People are attracted to the region by its natural scenery and beautiful landscapes. Bird watching has become internationally popular in the region and natural ecosystems are often used as places for recreation, including sport fishing. The biome also offers cultural traditions and folklore. 
- Medicinal and genetic attributes. The biome's biodiversity offers a diversity of life forms to be cultivated as crops and domesticated animals and also material for biotechnological experiments. It provides material for synthetic drugs used as medicines.

- Natural habitats and biodiversity. The Pantanal's natural systems provide living space for plants and animals which characterise its exuberant biodiversity, including genetic diversity. The different kinds of vegetation cover provide suitable shelters and other ecological resources to support a diversity of animal life. The heterogeneity of life forms is essential for maintaining all other ecosystem functions and services, as a result of millions of years of biological evolution. Maintenance of biodiversity is supported by natural ecosystems within such a large biome as is the case of the Pantanal. The biome's current order of its biodiversity magnitude depends upon its size (near 140,000 $\mathrm{km}^{2}$ ) and the heterogeneity of its different kinds of natural habitats. Vegetation cover prevents soil erosion and sediment control. It also works on fixation of solar energy and biomass production.

- Scientific attributes. The Pantanal offers numerous opportunities for scientific research, environmental education and monitoring environmental changes due to human occupation and impacts of development projects.

- Climate change. Vegetation cover, evaporation, regional and continental circulation patterns, like El Niño and La Niña, and water bodies, all interact to determine weather and climate. Seasonally flooded areas can be carbon sinks, which influence global climate change. The regional soil is composed of partially decayed accumulations of plants, and other organisms, resulting in stored carbon. The removal of carbon from the atmosphere depends on that carbon storage and vegetation cover. Estimates for the annual carbon accumulation in the Pantanal are not known, but the biome may play a significant role in the sequestration of carbon. There is a concerning trend about the future of Brazilian biomes regarding climate changing and the ecosystem processes. According to the United Nations Climate Change Conference held in Cancún, Mexico, in November-December 2010, studies on climate and hydrologic models in the Cerrado river basins pointed out toward a reduction of $20-25 \%$ of annual precipitation in 2100 , leading to a decrease of $7-10 \%$ in the volume of recharge of aquifers and in the river discharges, depending on the analysed scenario.

Ecosystem services provided by the Pantanal include maintenance of biodiversity, landscape, freshwater supply, fishery, nutrient cycling. These ecosystem services contribute to human quality of life. This important Brazilian biome requires sustainable management for its use and economic development, built on a new approach for the future, considering the inseparable relationship between economic development and human well-being to achieve sustainability. Scientific research can pave the way to reach this objective. Due to the rapid rate of environmental degradation, including altered hydrology, with loss of natural habitats and biodiversity, management strategies are imperative and urgent.

\section{References}

ALHO, CJR., 2005. The Pantanal. In LAUCHLAN, HF. and PAUL, AK., Org. The world's largest wetlands - Ecology and conservation. New York, USA: Cambridge University Press. p. $203-271$

-, 2008. The value of biodiversity. Brazilian Journal of Biology, vol. 68, no. 4, (Suppl.), p. 1115-1118.

BALMFORD, A., BRUNER, A., COOPER, P., COSTANZA, R., FARBER, S., GREEN, RE., JENKINS, M., JEFFERISS, P., JESSAMY, V., MADDEN, J., MUNRO, K., MYERS, N., NAEEM, S., PAAVOLA, J., RAYMENT, M., ROSENDO, S., ROUGHGARDEN, J., TRUMPER, K. and TURNER, RK., 2002. Economic reasons for conserving wild nature. Science, vol. 297, p. 950-953.

CARDINALE, BJ., SRIVASTAVA, DS., DUFFY, JE., WRIGHT, JP., DOWNING, AL., SANKARAN, M., JOUSEAU, C., CADOTTE, MW., CARROLL, IT., WEIS, JJ., HECTOR, A. and LOREAU, M., 2009. Effects of biodiversity on the functioning of ecosystems: summary of 164 experimental manipulations of species richness. Ecology, vol. 90, no. 3, p. 854. Ecological Archives E090-060.

CASARIN, R., 2007. Caracterização dos principais vetores de degradação ambiental da bacia hidrográfica Paraguai/ Diamantino. Rio de Janeiro: Instituto de Geociências, Programa de Pós-Graduação em Geografia, Universidade Federal do Rio de Janeiro. 169 p. Tese de doutotado em geografia.

CHIVIAN, E. and BERNSTEIN, A., Ed., 2008. How human health depends on biodiversity. New York: Oxford University Press. 566 p.

Conservação Internacional - CI, Ecologia e Ação - ECOA, Fundacíon AVINA, Instituto SOS Pantanal and WWF-Brasil. 2009. Monitoramento das alterações da cobertura vegetal e uso do solo na bacia do alto Paraguai - Porção brasileira - Período de análise: 2002 a 2008. Brasília. 58 p. Relatório técnico metodológico.

COSTANZA, R., D'ARGE, R., DE GROOT, R., FARBER, S., GRASSO, M., HANNON, B., LIMBURG, K., NAEEM, S., O'NEILL, RV., PARUELO, J., RASKIN, RG., SUTTON, P. and VAN DEN BELT, M., 1997. The value of the world's ecosystem services and natural capital. Nature, vol. 387, p. 253-260.

DAILY, GC., ALEXANDER, S., EHRLICH, PC., GOULDER, L., LUBCHENCO, J., MATSON, PA., MOONEY, HA., POSTEL, S., SCHNEIDER, SH., TILMAN, D. and WOODWELL, GM., 1997. Ecosystem services: benefits supplied to human societies by natural ecosystems. Washington, D.C.: Ecological Society of America.

DAILY, GC., Ed, 1997. Nature's services: societal dependence on natural ecosystems. Washington, D.C.: Island Press. 
DE GROOT, RS., WILSON, MA. and BOUMANS, RMJ., 2002. A typology for the classification, description, and valuation of ecosystem functions, goods, and services. Ecological Economics, vol. 41, p. 393-408.

KEDDY, PA., FRASER, LH., SOLOMESHCH, AI., JUNK, WJ., CAMPBELL, D., ARROYO, TK., ALHO, CJR., 2009. Wet and wonderful: the world's largest wetlands are conservation priorities. BioScience, vol. 59, no. 1, p. 39-51.

Millennium Ecosystem Assessment, 2003. Ecosystems and human well-being: a framework for assessment. Washington, D.C.: Island Press. The millennium ecosystem assessment series.

-, 2005a. Ecosystems and human well-being: current state and trends. vol. 1. Washington, D.C.: Island Press. The millennium ecosystem assessment series.

-, 2005b. Ecosystems and human well-being: scenarios. vol. 2. Washington, D.C.: Island Press. The millennium ecosystem assessment series.

-, 2005c. Ecosystems and human well-being: policy responses. vol. 3. Washington, D.C.: Island Press. The millennium ecosystem assessment series.

-, 2005d. Ecosystems and human well-being: multiscale assessments. vol. 4. Washington, D.C.: Island Press. The millennium ecosystem assessment series.

-, 2005e. Ecosystems and human well-being: our human planet: summary for decision-makers. vol. 5. Washington, D.C.: Island Press. The millennium ecosystem assessment series.
-, 2005f. Ecosystems and human well-being: general synthesis. Washington, D.C.: Island Press. The millennium ecosystem assessment series.

-, 2005g. Ecosystems and human well-being: biodiversity synthesis. Washington, D.C.: Island Press. The millennium ecosystem assessment series.

-, 2005h. Ecosystems and human well-being: disertification synthesis. Washington, D.C.: Island Press. The millennium ecosystem assessment series.

-, 2005i. Ecosystems and human well-being: opportunities and challenges for business and industry. Washington, D.C.: Island Press. The millennium ecosystem assessment series.

-, 2005j. Ecosystems and human well-being: wetland and water synthesis. Washington, D.C.: Island Press. The millennium ecosystem assessment series.

-, 2005k. Ecosystems and human well-being: health synthesis. Washington, D.C.: Island Press. The millennium ecosystem assessment series.

MINDELL, DP., 2009. Environment and health: humans need biodiversity. Science, vol. 323, no. 5921, p. 1562-1563.

SILVA, JSV., ABDON, MM. and MORAES, JA. 2010. Desmatamento na bacia do Alto Paraguai no Brasil. In Anais do III Simpósio de Geotecnologias no Pantanal. 16-20 out. 2010, Cáceres, MT. Embrapa Informática Agropecuária/INPE. p. 458-467. 